\title{
分子標的薬時代における転移性脳腫瘍に対する治療戦略
}

\author{
井内 俊彦1)，新行内 雅斗 ${ }^{2)}$ ，原 竜介 ${ }^{3)}$ \\ 1）千葉県がんセンター脳神経外科，2）同 呼吸器内科，3）同 放射線治療部
}

\section{Treatment Strategies for Brain Metastases in the Era of Molecular Tar- geted Therapy}

\author{
Toshihiko Iuchi, M.D. ${ }^{1)}$, Masto Shingyoji, M.D. ${ }^{2)}$, and Ryusuke Hara, M.D. ${ }^{3)}$ \\ 1) Divisions of Neurological Surgery, Chiba Cancer Center, 2) Divisions of Respirology, Chiba Cancer Center, 3) Divisions of \\ Radiation Oncology, Chiba Cancer Center
}

Molecular targeted therapy dramatically had changed the treatment of cancer patients, and the significant effect of this treatment on control of brain metastases had also been reported. The emergence of such new treatment requires reconsideration of therapeutic strategies for brain metastases. Molecular targeted therapy had no limitation of size and number of the intracranial lesions, but unfortunately were probably not curative and had risks of systemic adverse events. On the other hand, stereotactic radiation therapy may be curative for smaller brain metastases, but had limitations such as the size and the number of lesions. As described, molecular targeted therapy as systemic treatment and stereotactic radiation therapy as local treatment are not competitive treatments but complementary and coordinated treatments. Although how to coordinate these treatments is the future subject, the treatment strategy for each patient should be carefully discussed and decided by neurosurgeons, medical oncologists and radiation oncologists.

(Received May 27, 2019 ; accepted July 16, 2019)

Key words : brain metastases, epidermal growth factor receptor, tyrosin kinase inhibitor, stereotactic radiation therapy

Jpn J Neurosurg（Tokyo）28: 715-723, 2019

\section{はじめに}

転移性脳腫瘍は非浸潤性発育をするものと考えられ, 局所治療としての放射線治療が長く標準的治療として認 められてきた。エビデンスに基づいた転移性脳腫瘍に対 する標準治療は全脳照射だが ${ }^{12)}$ ，ガンマナイフに代表さ 机る定位的放射線治療（stereotactic radiotherapy：SRT) のきわめて優れた腫瘍制御と, 全脳照射後の学習記憶障 害発生の䯚念から ${ }^{2)}$, 実臨床においては SRT が脳転移治 療の第 1 選択とされている ${ }^{12)}$.
一方，がんに対する全身治療は殺細胞性抗がん剂を用 いた抗がん剤治療が主体だったが，分子標的治療や免疫 チェックポイント阻害剤を用いた治療などが導入され， その治療法はダイナミックに変化している.

ここでは，脳転移の発生と血液脳関門に対する概念の 変化を紹介したうえで, epidermal growth factor receptor $(E G F R)$ 遺伝子変異を有する非小細胞肺がん由来の脳転 移に対するチロシンキナーゼ阻害剤（TKI）の効果と問 題点を紹介し，今後の脳転移に対する治療戦略について 概説する。

連絡先：井内俊彦，干 260-8717 千葉市中央区仁戸名町 666-2 千葉県がんセンター脳神経外科

Address reprint requests to: Toshihiko Iuchi, M.D., Divisions of Neurological Surgery, Chiba Cancer Center, 666-2 Nitona-cho, Chuo-ku, Chiba-shi, Chiba 260-8717, Japan 


\section{脳転移の形成と血液腫瘍関門}

脳転移は血行性転移として形成される。すなわち，が ん細胞塊が血流によって頭蓋内に運ばれ，細動脈で捕捉 されてその部位で成長すると考えられてきた。しかし， いったん細動脈によって捕捉された細胞塊も時間が経つ と再び末梢に流れていくことが確認されて7)，単純に物理 的な細動脈による捕捉のみで脳転移が形成されるわけで はないと考えられている。一方，細動脈に捕捉され一定 時間そこに留まった細胞の一部が，血液脳関門（bloodbrain barrier：BBB）の tight junction を破壊して血管外に 移動することも判明した。その機序として胎盤成長因子 $p^{7)}$, cathepsin $\mathrm{S}^{14)}$, miR-181 $\mathrm{c}^{21)}$ など, さまざまな分子 の関与が報告されているが，いずれにしてもがん細胞が 自ら分泌する分子によって BBB を破壊して能動的に血 管外に移動していることが明らかとなっている。

血管外に移動した腫瘍細胞は，そこで成長し脳転移巣 を形成する。その形成機序には，悪性黒色腫のように腫 瘍細胞が血管周囲を取り囲むように移動し血管を捕捉し つつ成長する vascular cooption と, 非小細胞肺がんのよ うに腫瘍細胞が vascular endothelial growth factor(VEGF) を分泌し新生血管を引き込みながら成長する angiogene-

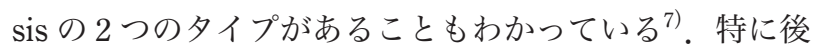
者において腫瘍細胞から分泌されるVEGF は血管内皮細 胞におけるアクチンの局在を変化させることにより tight junction を破壊することも知られている8).

このように，脳転移巣を形成する過程においてがん細 胞から分泌される分子は BBB を部分的ではあれ破壊し ており,このことは本来漏出することのない造影剤が腫 瘍部位に揸いて漏出し, 造影病変として画像上描出され ることからも理解される。したがって最近では，脳転移 病巣において部分的に機能破綻した BBB を, BBB とは 区別して血液腫瘍関門と表現されることも多くなった。

\section{分子標的と脳転移}

がんの分子環境が解明されるにつれ，がん細胞に特異 的な分子を標的とした分子標的治療が全身治療において 大きなウェイトを占めるょうになってきた。代表的な分 子標的としては非小細胞肺がんの $E G F R$ 遺伝子変異 • $A L K$ 融合遺伝子 $\cdot R O S 1$ 融合遺伝子 $B R A F$ 遺伝子変異, 乳がんの Her2 増幅, 悪性黒色腫の $B R A F$ 遺伝子変異な どが挙げられる。

これらの分子異常の中で, 非小細胞肺がんにおける $E G F R$ 遺伝子変異はその頻度に人種差があり特に東アジ
アで多く，本邦における頻度は $33 \%$ と報告されてい $3^{16)}$. 一方, EGFR 遺伝子変異を有する非小細胞肺がん は脳転移をきたしやすく ${ }^{6)}$ ，その頻度から本邦において 脳転移を有する非小細胞肺がんの半数近くが $E G F R$ 遺伝 子変異陽性と推測される。このことは，脳転移例の半数 近くがTKIを用いた全身治療を受ける可能性があること を意味している.

\section{脳転移病巣に対する分子標的薬の効果}

$E G F R$ 遺伝子変異を有する非小細胞肺がんに対する TKI としては, 第 1 世代のゲフィチニブ・エルロチニブ, 第 2 世代のアファチニブ, 第 3 世代のオシメルチニブが 本邦でも保険収載されている。分子標的薬の脳転移に対 する奏効率の報告をみると，報告により試験の条件や背 景が異なるため薬剤間の比較はできないものの，いずれ の分子標的薬も劇的な効果を示しており，前述した BBB 破壊の概念と重なり，脳病変に対する全身治療の効果が

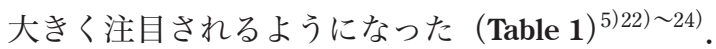

わ机わは, $E G F R$ 遺伝子変異陽性非小細胞肺がん由 来脳転移症例のうち，頭蓋外にも活動性病変を有する患 者，すなわち頭蓋内に対する局所治療のいかんにかかわ らず全身治療としてTKI治療を行う予定がある症例を対 象に，TKI 治療を先行させ，TKI の頭蓋内病変に対する 単独効果を評価している，頭部に対する放射線治療歴の ない 163 例に対して施行した 256 回の TKI 治療（ゲフィ チニブ 97 ，エルロチニブ 88 ，アファチニブ 31 ，オシメ ルチニブ 40）の脳転移巣に対する単独効果をみると, 完 全奏効 $32 \%$, 部分奏効 $41 \%$, 安定 $21 \%$, 増大 $6 \%$ で, 奏 効率は $73 \%$ に至った（Fig. 1)。 また，TKI の投与期間を その中止理由（中枢神経系再発，頭蓋外再発，副作用） で競合リスク解析すると, 治療開始後 1 年時点での中枢 神経系再発率は $28.7 \%$ で，頭蓋外再発率の $26.7 \%$ とほぼ 同等であり (Fig. 2), 脳転移病巣に対しても原発巣を含 めた頭蓋外病変と同等の治療効果が期待できることが示 された。

このように, 全身治療としての TKI が頭蓋内病変に対 してもきわめて有効であることが判明したことにより， これまでの転移性脳腫瘍の治療概念は大きく変化してい る. Disease-Specific Graded Prognostic Assessment (DSGPA）分類は日常的に使用される転移性脳腫瘍患者の予 後評価ツールだが18)，最近肺がんに関する分類が $E G F R$ 遺伝子変異ならびに $A L K$ 融合遺伝子の項目を加えた Lung-molGPA に改変された ${ }^{19)}$. 従来より転移性脳腫瘍患 者の予後を最も強く規定する因子は頭蓋外活動性病変の 
有無であると考えられてきたが，興味深いことに LungmolGPA 改訂の根拠となったデー夕をみると, 転移性脳 腫瘍患者の予後に関するハザード比は，活動性頭蓋外病 変の有無の 0.47 に対し, 分子標的の有無が 0.48 とほぼ同 等の值を示している。このことは, 分子標的の存在とそ れに対する有効な分子標的薬の存在の意義の大きさを示 している.

\section{分子標的治療の問題点}

TKI は頭蓋内病変に対してもきわめて有効であるが, 一方で治癒的ではないという問題点も抱えている. Fig. 3 はゲフィチニブを用いて治療を行った症例であるが, 治療によりいったん消失した病変がゲフィチニブ終了後 に同一部位から再発しているのが確認される。この分子 標的薬の非根治性の原因の 1 つとして腫瘍病変の不均質 性が挙げられる。がん病巣は必ずしも均質な細胞集団と はかぎらず，不均質な分子環境を有する細胞の集合体で あることが多いと考えられている. 分子標的治療は 1 つ の分子標的を攻撃するため，その分子標的を有する細胞 は除去されるが，他の分子環境を有する細胞は生存し続 け，いずれ再発をきたす ${ }^{14)}$. 一方，治療の過程において 新たな遺伝子変異をきたし耐性を獲得する機序も報告さ れており, T790M 変異はその代表的な遺伝子変異であ
る。いずれにしても，分子標的治療では初発時と再発時 には腫瘍の分子環境が変化していることが推測され, 再 発病変に対する治療戦略を考えるうえで, 再生検による 分子環境の確認が重要となる。オシメルチニブは当初こ の T790M 変異を有する症例に対する治療法として認可 されており，現在でも第 1 世代・第 2 世代の TKI 治療歴 のある患者においては T790M 変異の出現が保険治療の 条件とされている。したがって，この薬剤の適応を決定 するうえで再生検による分子診断は必須である。

再生検の方法としては気管支鏡検査によるサンプル採 取が一般的に行われているが，最近ではより低侵襲な方 法として血液を用いたりキッドバイオプシーも行われる

Table 1 EGFR-TKI : Prospective trials directly reporting CNS de novo response rates

\begin{tabular}{l|c|c|l}
\hline \multicolumn{1}{c|}{ Agent } & $\begin{array}{c}\text { Number of } \\
\text { patients }\end{array}$ & $\begin{array}{c}\text { CNS response } \\
\text { rate }\end{array}$ & Reference \\
\hline Gefitinib & 41 & $85 \%$ & Iuchi T) $^{5)}$ \\
Erlotinib & 48 & $58 \%$ & Wu YL $^{23)}$ \\
Afatinib & 71 & $81 \%$ & Wei YF $^{22}$ \\
$\begin{array}{l}\text { Osimertinib } \\
\text { (pre-treated, }\end{array}$ & 30 & $70 \%$ & Wu YL $^{24)}$ \\
T790M+) & & & \\
\hline
\end{tabular}

*retrospective analyses

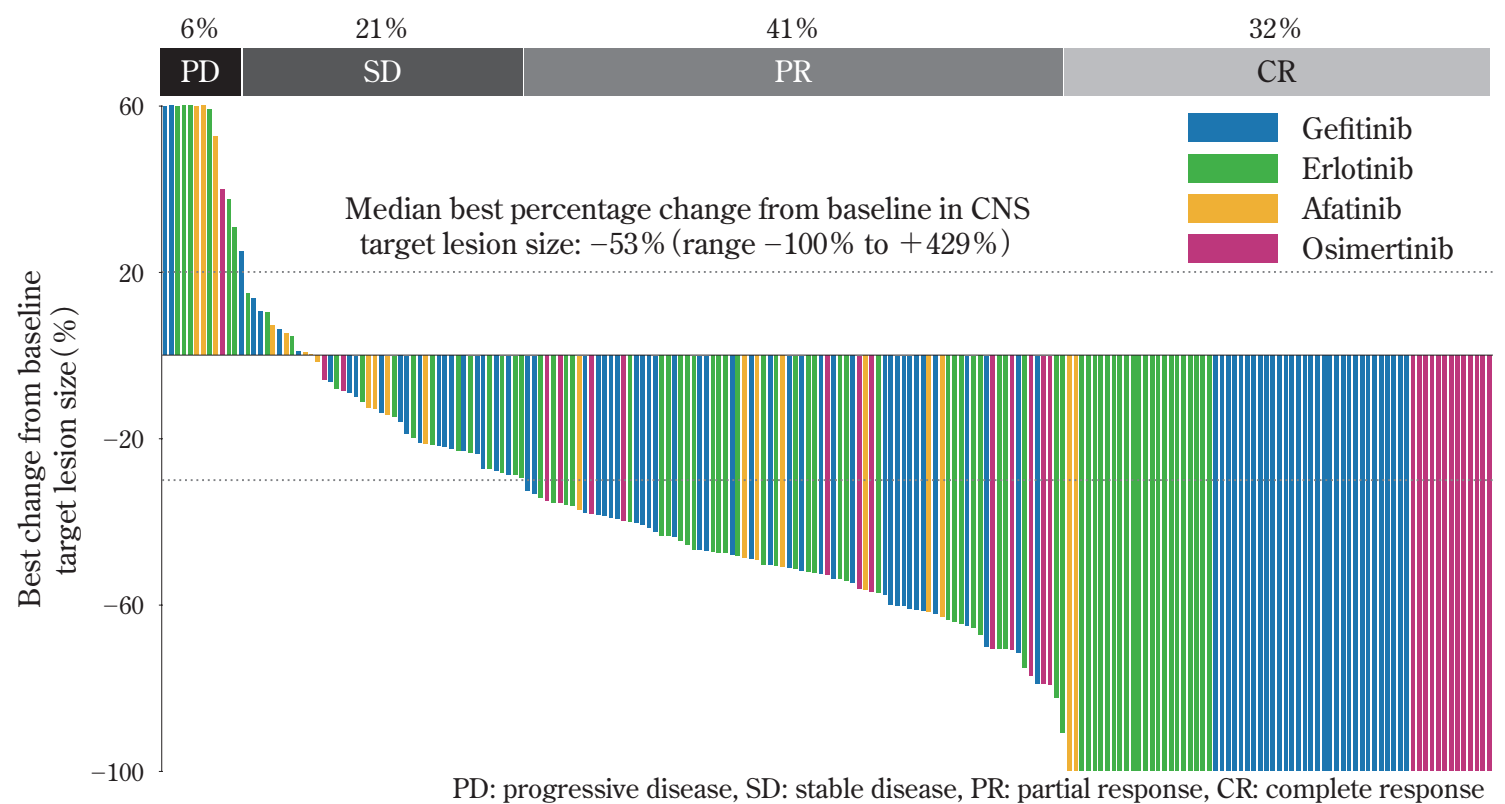

Fig. 1 Responses of brain metastases against tyrosine kinase inhibitors

Target lesion was decided as the largest CNS lesion on MRI. Best percentage change in target lesion size was the maximum reduction from baseline or minimum increase from baseline in the absence of a reduction. 


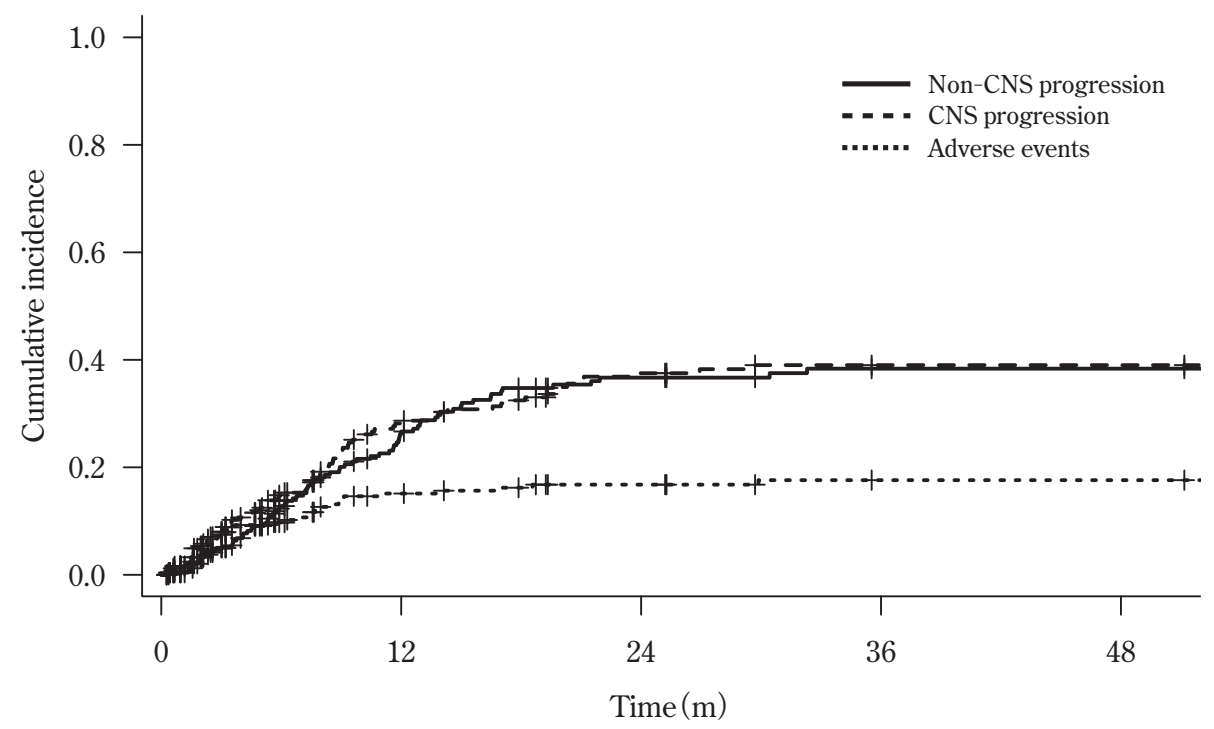

Fig. 2 Duration of responses of brain metastases

The probability of experiencing a CNS progression event was not different with that of experiencing non-CNS progression after administration of tyrosine kinase inhibitors. Competing risks were defined as non-CNS progression, CNS progression and adverse events in the absence of non-CNS or CNS progression.
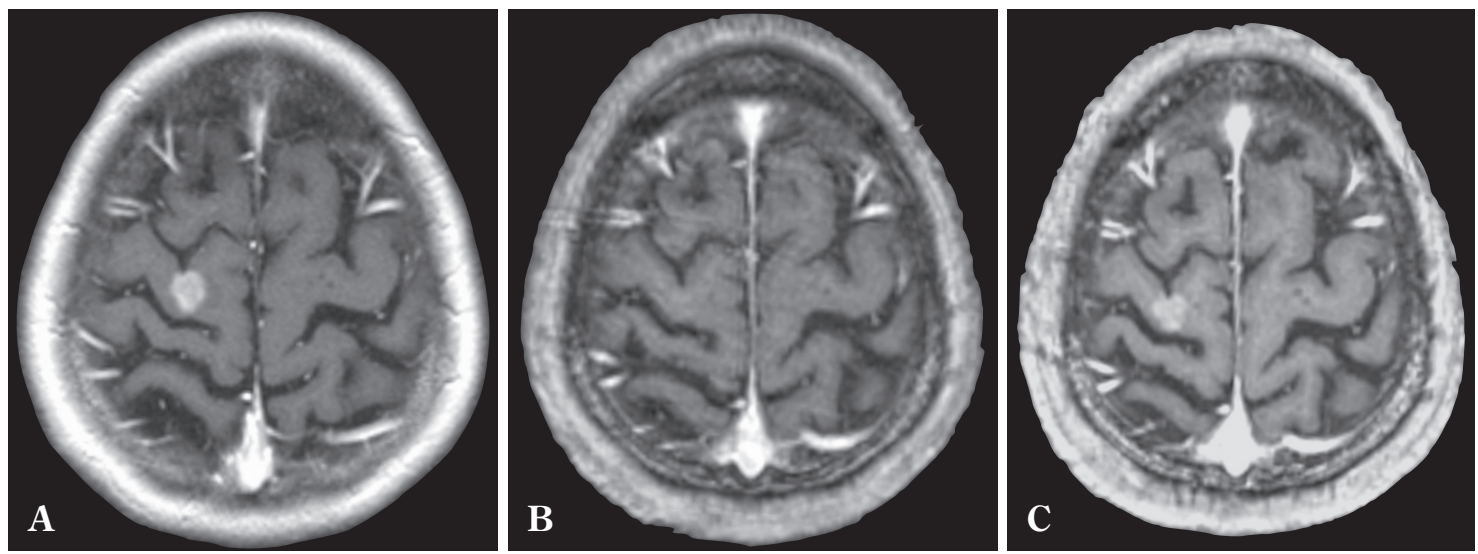

Fig. 3 A representative case of EGFR-mutated case treated by gefitinib

Enhanced MRIs at onset (A), after gefitinib (B), and 3 months after withdrawal of gefitinib (C). Brain metastases in the right high frontal lesion disappeared by gefitinib on images, but regrowth of the lesion was observed after withdrawal of this agent.

ようになった。しかし，組織診断である気管支鏡検査に 比較すると血清診断では腫瘍情報そのものが得られない 陰性検査となる可能性も高いなどの問題も抱えている. 実際当院で気管支鏡検査を行い再生検した 58 サンプル では腫瘍遺伝子を全例で確認できたのに対し，血清の 37 サンプルでは 7 例 $(18.9 \%)$ において腫瘍遺伝子を確認 できなかった。

一方，中枢神経系のリキッドバイオプシーとして髄液 を用いた分子診断も行われている。髄液細胞診で悪性細
胞が確認された症例に対して行ったわれわれの 21 例の 検討では全例で腫瘍情報を確認できており髄膜播種症例 では有効な再生検方法となっている。

分子標的薬治療の根治性が低いもう1つの原因とし て, 腫瘍における BBB 破綻の不均質性を挙げることが できる，前述したように腫瘍部においては腫瘍細胞が分 泌する分子により $\mathrm{BBB}$ が破壊されているが，その破壊 の程度には, 病巣内でも病巣間でも不均質性が存在する ことが報告されており ${ }^{9)}, E G F R-T K I$ の有効性に血液腫 
Table 2 Characteristics of molecular targeted therapy and stereotactic radiation therapy

\begin{tabular}{l|l|l}
\hline & Tyrosine kinase inhibitors & Stereotactic radiation therapy \\
\hline Control of solid BMs & $\begin{array}{l}\text { Effective but } \\
\text { may not curable }\end{array}$ & May curable \\
Size of BMs & No limitation & Up to 2 or $3 \mathrm{~cm}$ \\
Number of BMs & No limitation & Up to 7-10 \\
Control of LMCs & Effective & No effect \\
CNS toxicity & Not reported & Radiation necrosis \\
Control of extracranial lesions & Effective & No effect \\
Systemic toxicity & Pneumonitis & No \\
& Liver dysfunction & \\
& Skin eruption & \\
\hline
\end{tabular}

BMs : brain metastases, LMCs : leptomeningeal carcinomatoses

瘍関門を介した薬剤透過性の不均質性が多少なりとも影 響している可能性がある. FLAURA 試験の結果を受けて 初発時から投与が可能となったオシメルチニブは ${ }^{17)}$ ，第 1 世代・第 2 世代の $E G F R-T K I$ に比較してきわめて良好 な $\mathrm{BBB}$ 透過性を示す ${ }^{1)}$. 今後脳転移を有する症例に対す る同薬剤の使用経験が蓄積することで, BBB 透過性がど の程度治療の有効性に影響するか明らかになるものと思 われる。

\section{分子標的治療と定位的放射線治療}

前述したようにTKIによる全身治療は脳転移に対して もきわめて高い効果を示す。この治療法は脳転移病巣の 大きさ・数などの制限はなく髄膜がん腫症に対しても有 効であるといつた利点を有する一方，根治性が低い問題 点も抱えている，脳転移を有する時点でその患者はス テージIVに分類され一般的には予後は限られるが，肺が んでは脳が唯一の遠隔転移である症例も多く，また病初 期に脳転移を伴うことも多い.このような症例において は，頭蓋内制御がその後の予後を決定することもあり， 治療の根治性を求められる場面において分子標的薬単独 での治療では不十分となることが多い.

SRT は, 侵襲性が比較的少なく根治性が高い。ただ, この治療は腫瘍のサイズが大きくなると腫瘍制御が不良 となり，その至適閾值は直径約 $10 \mathrm{~mm}$ と報告されてい る ${ }^{3)}$ ，その原因として，特に単回照射では腫瘍サイズが 大きくなるにつれ放射線脳障害のリスクが上昇すること から治療線量を減量せざるを得ないことが挙げられてい る ${ }^{15)}$. 少なくとも直径 $20 \mathrm{~mm}$ 以上の病変に対しては定位 照射を分割することで放射線障害のリスクを下げるべき だとの指摘もあり ${ }^{11)}$ ，このサイズを超える症例では根治
性と放射線障害のリスクの点で問題が残つている.

病変の数もまた，SRTを制限する因子となっている。 従来のガイドラインでは 4 個までの少数個がSRT の適応 とされているが13)，本邦で行われたガンマナイフによる 転移性脳腫瘍治療成績をみた非ランダム化前向き試験 （JLGK0901）において脳転移が 2〜4 個までの症例と 5〜 10 個までの症例で生命予後に差がなかったことから ${ }^{25)}$, 最近では 10 個程度までであれば SRTで治療可能と考え られている。一方, JLGK0901試験における新病巣出現 率は，治療後 1 年の時点で 36.7〜 $63.8 \%$ と報告されてい る. SRT は局所治療であり, 新しい転移の予防や occult 病変の治療を目的とした治療ではないが，われわれの TKI 単独治療後 1 年での中枢神経系再発率が局所再発と 新病巣出現を併せて $28.7 \%$ であたことを考慮すると， 特に長期の予後が期待される症例における全脳制御の重 要性も示唆される.

このように，分子標的治療と SRT はいずれも頭蓋内病 変に対して有効であるが，全身治療と局所治療というそ の治療の本質に基づいて，それぞれに利点と課題を有し ている。分子標的治療は，対象とする脳病変の数や大き さに制限がなく髄膜がん腫症にも有効だが根治性には欠 ける.SRT は根治性は高いが，治療できる脳病変の数や 大きさに制限があり髄膜がん腫症には無効である。分子 標的薬は中枢神経系合併症がほとんどなく，頭蓋外病変 に対しても効果が期待できるが皮疹や肝機能障害，とき に間質性肺炎といつた全身性有害事象のリスクを有す る.SRT は全身性合併症は認めないが頭蓋外病変には無 効であり，脳においては放射線脳壊死のリスクを有する (Table 2).このようにみると, 分子標的治療と SRT は, お互いに競合する治療法ではなく相互補完的に協調し得 る治療法であることが理解できる。 
分子標的治療と SRT をどのように協調させるべきか に関しては，現時点でランダム化試験の報告はなく今後 の課題となっている。ただ，分子標的治療は SRTに比較 して根治性に劣ること，全身性合併症のリスクを有する ことから, 脳以外に活動性病変を認めない症例に対する 適応には慎重になるべきである。医療経済的にも，一度 の治療で終了するSRTに比較して, 治療継続が原則の TKI は治療コストが大きくなることが懸念される，TKI と SRTのどちらを先行させるかも今後の課題である. 後 方視的検討から SRT 先行の優位性も報告されている が10)，この報告に登録された症例では頭蓋外に転移を有

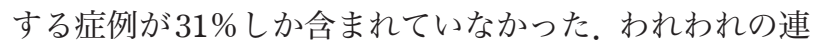
続 1,143 例の肺がんの検討では, EGFR 遺伝子変異陽性 の脳転移例では半数以上 $(52 \%)$ で頭蓋外転移も有して おり ${ }^{6)}$, 明らかにこの報告の症例分布は実臨床と乘離し ている。 また，頭蓋外に転移のない $69 \%$ の症例はそもそ も SRT 単独治療の適応であり TKI 治療の適応は乏しい. このように，その特異な患者背景と治療適応への疑問か ら, 残念ながらこの研究から得られる情報は少なく, よ り正確な情報の発信が待たれている.

\section{分子標的治療と脳外科手術}

分子標的薬は奏効率が高いものの必ず効果を示すとは かぎらず，診断時すでに症候性となっている病変や eloquent 領域近傍の比較的大きな病変は外科的摘出の適応 である，担がん患者において生命予後を規定するのは頭 蓋外病変の制御であり全身治療に依存する部分が大き い。したがって，転移性脳腫瘍手術の目的は，患者の神 経機能喪失を予防または回復させ，全身治療が可能な performance status（PS）を維持することである。 そのた めには, 術前の tractographyなどを駆使した機能評価や, 術中機能マッピング, 覚醒下手術などの手技を駆使し, 低侵襲機能温存に徹することが重要となる。

一方，分子標的薬時代になり再発時の分子環境評価を 目的として, 再生検として脳転移病巣の摘出も行われる ようになった。特に, $E G F R$ 遺伝子変異陽性非小細胞肺 がんからの脳転移は脳表近くに発生しやすく ${ }^{20)}$, このこ とは比較的低侵襲に脳病変を摘出可能であることを示し ている。磁場式ナビゲーションシステムなどの手術支援 装置と key-hole 手技を用い机ばフレームレスでの脳転 移病巣摘出も可能であり, 今後より低侵襲な脳転移病巣 の再生検法を開発することで頭蓋内病巣の分子環境評価 を積極的に行っていく環境を整えていくことが脳神経外 科医の責務である.
髄膜がん腫症はがんの最も重篤な中枢神経系浸潤であ るが, $E G F R$ 遺伝子変異陽性肺がん由来脳転移自験例 229 例の検討では， 5 年の経過観察期間中に $33 \%$ の症例 で髄膜がん腫症の発症を認めた（Fig. 4)。一方，髄膜が ん腫症患者の $69 \%$ で頭蓋内圧方進症状をきたしており, 頭蓋内圧の制御は患者の quality of life を維持するうえで も，また全身治療の機会を確保するうえでも重要とな る。髄膜がん腫症による水頭症に対する脳室腹腔短絡術 は髄液中の腫瘍細胞を腹腔内に誘導するといった懸念も 指摘されているが実臨床でがん性腹膜炎が問題となるこ とはほとんどなく，この手術を躊躇する必要はない。し かし，EGFR 遺伝子変異陽性肺がん由来の髄膜がん腫症 では分子標的治療により頭蓋内圧も正常化することが多 い。われわれは，まずオンマイヤリザーバーを留置し， これを介した外ドレナージで頭蓋内圧制御を行いつつ分 子標的治療を行い，頭蓋内压立進症状が改善しない症例 にのみ脳室腹腔短絡術を追加しているが，これまでこの 方針で治療を行った 26 例中 14 例で短絡術を回避でき た。今後はこのような外科的治療と分子標的治療との sequential な協調も重要となる。

\section{分子標的薬時代の脳転移治療}

ここでは, 症例が多いことから EGFR-TKIについて紹 介したが, $A L K$ 融合遺伝子陽性例に対する $A L K$ 阻害剂 も頭蓋内病変に対して著効する。ただ，この治療もまた 根治性は低くSRT との協調が重要となる。分子標的治療 の性格は，全脳制御という観点からは従来の全脳照射に 近く，正常脳に対する安全性から全脳照射にとって変わ る可能性がある。多発転移性脳腫瘍に対して分子標的薬 を使用し縮小が不十分な病変に SRT を追加したり，分子 標的薬で安全に SRT が施行できるサイズまで腫瘍を縮 小させたうえで根治的 SRT を行うなど，その協調方法は 多岐にわたり，今後は症例ごとに治療法の選択や治療の 順番なぞを慎重に決定していく必要がある。そのために は，脳神経外科医，腫瘍内科医，放射線治療医，病理診 断医，遺伝子診断医がしつかりと情報共有し意思疎通し ながら治療方針を話し合い決定していくことが求められ ている。

\section{おわりに}

分子標的薬に加えて免疫チェックポイント阻害剤を用 いた治療も一般的となり，全身治療の進歩は日進月歩で ある。これは患者にとって福音である一方，われわれ脳 


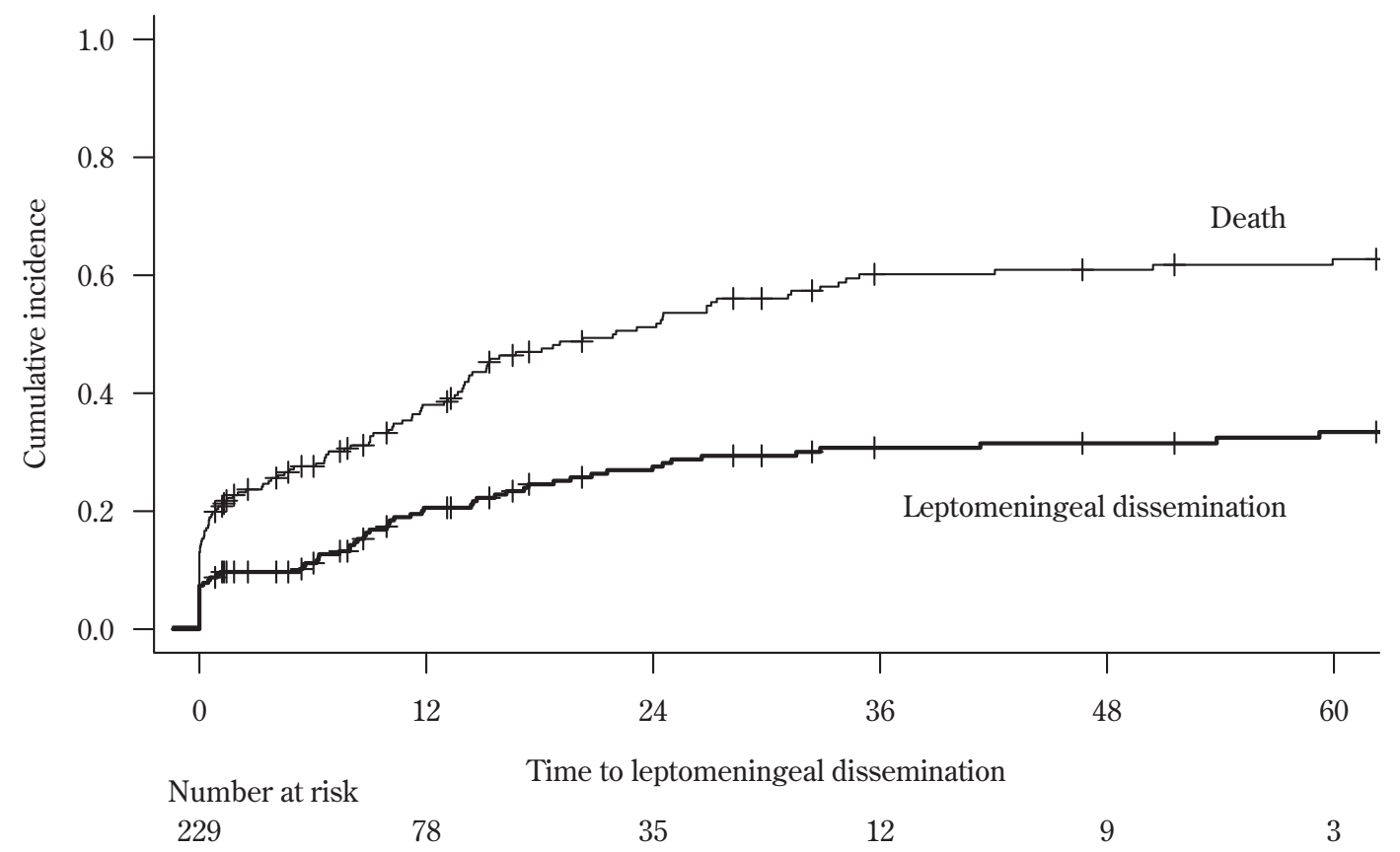

Fig. 4 Competing risk analysis of the time to leptomeningeal dissemination after diagnosis of brain metastases in EGFR-mutated cases

The probability of experiencing a leptomeningeal dissemination in the absence of death was $33.4 \%$ at 5 years after the diagnosis of brain metastasis.

神経外科医がこれらすべての治療情報をリアルタイムに 正確に把握することは困難になってきている．1人 1 人 の患者がその人にとって最も適した治療を受けられる機 会を提供するためには，キャンサーボードなどを介した 他診療科の医師との高レベルでの協調が求められている.

筆頭著者は日本脳神経外科学会への COI 申告の登録を完了 しています。また，新行内，原の両著者は，自己申告による COI 報告書を日本脳神経外科コングレス事務局に提出してい ます。いずれも本論文に関して開示すべきCOIはありません。

\section{文 献}

1) Ballard P, Yates JW, Yang Z, Kim DW, Yang JC, Cantarini M, Pickup K, Jordan A, Hickey M, Grist M, Box M, Johnström P, Varnäs K, Malmquist J, Thress KS, Jänne PA, Cross D : Preclinical comparison of osimertinib with other EGFRTKIs in EGFR-mutant NSCLC brain metastases models, and early evidence of clinical brain metastases activity. Clin Cancer Res 22: 5130-5140, 2016.

2) Chan EL, Wefel JS, Hess KR, Allen PK, Lang FF, Komguth DG, Arbuckle RB, Swint JM, Shiu AS, Maor MH, Meyers $\mathrm{CA}$ : Neurocognition in patients with brain metastases treated with radiosurgery or radiosurgery plus whole-brain irradiation: a randomized controlled trial. Lancet Oncol 10: 1037-1044, 2009.

3) Garsa AA, Badiyan SN, DeWees T, Simpson JR, Huang J, Drzymala RE, Barani IJ, Dowling JL, Rich KM, Chicoine MR, Kim AH, Leuthardt EC, Robinson CG : Predictors of individual tumor local control after stereotactic radiosurgery for non-small cell lung cancer brain metastases. Int J Radiat Oncol Biol Phys $90:$ 407-413, 2014.

4) Ichihara E, Lovly CM : Shades of T790M : Intratumor heterogeneity in EGFR-mutant lung cancer. Cancer Discov 5: 694-696, 2015.

5) Iuchi T, Shingyoji M, Sakaida T, Hatano K, Nagano O, Itakura M, Kageyama H, Yokoi S, Hasegawa Y, Kawasaki K, Iizasa $\mathrm{T}$ : Phase II trial of gefitinib alone without radiation therapy for Japanese patients with brain metastases from EGFRmutant lung adenocarcinoma. Lung Cancer $82: 282-287$, 2013.

6) Iuchi T, Shingyoji M, Itakura M, Yokoi S, Moriya Y, Tamura H, Yoshida Y, Ashinuma H, Kawasaki K, Hasegawa Y, Sakaida T, lizasa T : Frequency of brain metastases in nonsmall-cell lung cancer, and their association with epidermal growth factor receptor mutations. Int J Clin Oncol 20 : 674-679, 2015.

7) Kienast Y, von Baumgarten L, Fuhrmann M, Klinkert WE, Goldbrunner R, Herms J, Winkler F : Real-time imaging reveals the single steps of brain metastasis formation. Nat Med 16: 116-22, 2010.

8) Lee TH, Avraham HK, Jiang S, Avraham S : Vascular endothelial growth factor modulates the transendothelial migration of MDA-MB-231 breast cancer cells through regulation of brain microvascular endothelial cell permeability. J Bio Chem 278: 5277-5284, 2003.

9) Lockman PR, Mittapalli RK, Taskar KS, Rudraraju V, Gril B, Bohn KA, Adkins CE, Roberts A, Thorsheim HR, Gaasch JA, Huang S, Palmieri D, Steeg PS, Smith QR : Heterogeneous blood-tumor barrier permeability determines drug 
efficacy in experimental brain metastases of breast cancer. Clin Cancer Res $16: 5664-5678,2010$.

10) Magnuson WJ, Lester-Coll NH, Wu AJ, Yang TJ, Lockney NA, Gerber NK, Beal K, Amini A, Patil T, Kavanagh BD, Camidge DR, Braunstein SE, Boreta LC, Balasubramanian SK, Ahluwalia MS, Rana NG, Attia A, Gettinger SN, Contessa JN, Yu JB, Chiang VL : Management of brain metastases in tyrosine kinase inhibitor-naïve epidermal growth factor receptor-mutant non-small-cell lung cancer : A retrospective multi-institutional analysis. J Clin Oncol 35 : 1070-1077, 2017.

11) Minniti G, Scaringi C, Paolini S, Lanzetta G, Romano A, Cicone F, Osti M, Enrici RM, Esposito V : Single-fraction versus multifraction $(3 \times 9 \mathrm{~Gy})$ stereotactic radiosurgery for large $(>2 \mathrm{~cm})$ brain metastases: A comparative analysis of local control and risk of radiation-induced brain necrosis. Int J Radiat Oncol Biol Phys 95 : 1142-1148, 2016.

12）日本肺癌学会編：肺癌診療ガイドライン 2018 年版. 東 京，金原出版，2018。

13）日本脳腫瘍学会編：脳腫瘍診療ガイドライン 2019 版. https://www.jsn-o.com/guideline/index1.html（2019 年 5 月）

14) Sevenich L, Bowman RL, Mason SD, Quail DF1, Rapaport F, Elie BT, Brogi E, Brastianos PK, Hahn WC, Holsinger LJ, Massagué J, Leslie CS, Joyce JA : Analysis of tumour- and stroma-supplied proteolytic networks reveals a brainmetastasis-promoting role for cathepsin S. Nat Cell Biol $16: 876^{-888,} 2014$.

15) Shaw E, Scott C, Souhami L, Dinapoli R, Kline R, Loeffler J, Farnan $\mathrm{N}$ : Single dose radiosurgical treatment of recurrent previously irradiated primary brain tumors and brain metastases : final report of RTOG protocol 90-05. Int J Radiat Oncol Biol Phys $47: 291-298,2000$.

16) Shigematsu H, Gazdar AF : Somatic mutations of epidermal growth factor receptor signaling pathway in lung cancers. Int J Cancer 118: 257-262, 2006.

17) Soria JC, Ohe Y, Vansteenkiste J, Reungwetwattana T, Chewaskulyong B, Lee KH, Dechaphunkul A, Imamura F, Nogami N, Kurata T, Okamoto I, Zhou C, Cho BC, Cheng Y, Cho EK, Voon PJ, Planchard D, Su WC, Gray JE, Lee SM, Hodge R, Marotti M, Rukazenkov Y, Ramalingam SS ; FLAURA Investigators: Osimertinib in untreated EGFR-mutated advanced non-small-cell lung cancer. $N$ Engl J Med $\mathbf{3 7 8}$ : 113-125, 2018.

18) Sperduto PW, Chao ST, Sneed PK, Luo X, Suh J, Roberge D, Bhatt A, Jensen AW, Brown PD, Shih H, Kirkpatrick J, Schwer A, Gaspar LE, Fiveash JB, Chiang V, Knisely J, Sperduto CM, Mehta M : Diagnosis-specific prognostic factors, indexes, and treatment outcomes for patients with newly diagnosed brain metastases : a multi-institutional analysis of 4,259 patients. Int J Radiat Oncol Biol Phys 77: 655-661, 2010.

19) Sperduto PW, Yang TJ, Beal K, Pan H, Brown PD, Bangdiwala A, Shanley R, Yeh N, Gaspar LE, Braunstein S, Sneed P, Boyle J, Kirkpatrick JP, Mak KS, Shih HA, Engelman A, Roberge D, Arvold ND, Alexander B, Awad MM, Contessa J, Chiang V, Hardie J, Ma D, Lou E, Sperduto W, Mehta MP : Estimating survival in patients with lung cancer and brain metastases : An update of the graded prognostic assessment for lung cancer using molecular markers (Lung-molGPA). JAMA Oncol $3:$ 827-831, 2017.

20) Takano K, Kinoshita M, Takagaki M, Sakai M, Tateishi S, Achiha T, Hirayama R, Nishino K, Uchida J, Kumagai T, Okami J, Kawaguchi A, Hashimoto N, Nakanishi K, Imamura F, Higashiyama M, Yoshimine $\mathrm{T}$ : Different spatial distributions of brain metastases from lung cancer by histological subtype and mutation status of epidermal growth factor receptor. Neuro Oncol 18: 716-724, 2016.

21) Tominaga N, Kosaka N, Ono M, Katsuda T, Yoshioka Y, Tamura K, Lötvall J, Nakagama H, Ochiya T : Brain metastatic cancer cells release microRNA-181 $\mathrm{c}^{-}$containing extracellular vesicles capable of destructing blood-brain barrier. Nat Commun $\quad \mathbf{6}: 6716,2015$.

22) Wei YF, Lim CK, Tsai MS, Huang MS, Chen KY : Intracranial responses to afatinib at different doses in patients with EGFR-mutated non-small-cell lung carcinoma and brain metastases. Clin Lung Cancer 20 : e274-e283, 2019.

23) Wu YL, Zhou C, Cheng Y, Lu S, Chen GY, Huang C, Huang YS, Yan HH, Ren S, Liu Y, Yang JJ : Erlotinib as second-line treatment in patients with advanced non-small-cell lung cancer and asymptomatic brain metastases: a phase II study (CTONG-0803). Ann Oncol 24: 993-999, 2013.

24) Wu YL, Ahn MJ, Garassino MC, Han JY, Katakami N, Kim HR, Hodge R, Kaur P, Brown AP, Ghiorghiu D, Papadimitrakopoulou VA, Mok TSK : CNS efficacy of osimertinib in patients with T790M-Positive advanced non-small-cell lung cancer: data from a randomized phase III trial (AURA3).J Clin Oncol 36:2702-2709, 2018.

25) Yamamoto M, Serizawa T, Shuto T, Akabane A, Higuchi $Y$, Kawagishi J, Yamanaka K, Sato Y, Jokura H, Yomo S, Nagano O, Kenai H, Moriki A, Suzuki S, Kida Y, Iwai Y, Hayashi M, Onishi H, Gondo M, Sato M, Akimitsu T, Kubo K, Kikuchi Y, Shibasaki T, Goto T, Takanashi M, Mori Y, Takakura K, Saeki N, Kunieda E, Aoyama H, Momoshima S, Tsuchiya K : Stereotactic radiosurgery for patients with multiple brain metastases (JLGK0901) : a multi-institutional prospective observational study. Lancet Oncol $\quad 15$ : 387-395, 2014. 
分子標的薬時代における転移性脳腫瘍に対する治療戦略

井内 俊彦新行内雅斗原竜介

分子標的薬の時代になりがん治療が大きく変化する中で, 分子標的薬が脳転移病巣に対しても有効 であることも報告され，転移性脳腫瘍に対する治療戦略の再考が求められている. 全身治療である分 子標的薬治療は脳転移病巣の大きさや数に制限がなく奏効率も高いが，根治性は低く全身性合併症の リスクもある. 一方, 局所治療である定位的放射線治療は根治性は高いが, 病変の大きさや数に制限 があり放射線脳障害のリスクもある．このようなそれぞれの治療法の特徵は，両治療が相互補完的に 協調し得ることを示しており, 今後は個々の患者に最も適した治療法を, 脳神経外科医・腫瘍内科 医・放射線治療医で綿密に検討して決定していくことが重要である. 